ORGANIZAÇÃo

\title{
Da Divisão do Trabalho à Organização
}

\author{
Benedicto Silva \\ Autor de A Era do Administrador \\ Profissional
}

66

A organização está submetida a leis. Essas leis são apenas duas: diversificação e agrupamento do trabalho, especialização e cooperação, divisão e integração. Não conseguiu a inteligência humana imaginar outras. Em organização, não importa o meio que o homem tenha de empregar, e qualquer que seja o método que tenha de seguir, sempre se trata da aplicação destas duas leis. Delas derivam os mais variados princípios de organização: centralização e descentralização, mecanização e automatização, concentração e distribuição" - diz Mellerovicz. (1)

"A divisão do trabalho é o fundamento da organização; em verdade, a sua razão de ser" - diz GuLı́ck. (2)

Tratarse de assunto amplamente examinado e debatido pelo direito e pelo avêsso. Seria estultice voltar a êle com pretensão de the acrescentar algo de nôvo. O presente ensaio, espécie de simpósio sem debates, tem por fim apenas reavivar o conceito de que a divisão do trabalho é a via essencial da organização. Justifica-se o simpósio porque muitos que se anunciam como organizadores ou racionalizadores no Brasil e alhures parecem esquecer o papel pragmático que a divisão do trabalho desempenha na ciência e arte da organização.

A fim de facilitar um confronto das generalidades doutrinárias, transcreverei, em primeiro lugar, excertos de algumas opiniões famosas sôbre a divisão do trabalho (de ADAm Smith, Henri Fayol e Luther Gulick), por mim traduzidos dos res pectivos originais para êste ensaio. Em seguida, tentarei distinguir entre divisão natural e divisão refletida do trabalho. A arte de organizar cientificamente consiste em substituir a divisão na -

(1) K. Mel.terovicz, Teoria Económica de las Exploraciones, Editorial Labor, Barcelona, 1936, p. 268.

(2) L. Gulick, "Notes on the Theory of Organizacion", in Papers on the Science of Adiministration, Nova Iorque, 1937, p. 3. 
tural pela refletida, de modo que as duas leis que comandam a organização possam atuar em condições ótimas. Por fim, tecerei, numa espécie de P. S. exemplificativo, em estilo de aplicação, algumas considerações gerais sôbre a divisão do trabalho no govêrno federal do Brasil.

\section{II}

Começamos por FAYol. Para êle, a divisão do trabalho é um principio administrativo, o princípio número um de sua lista de quatorze. Talvez por isso, seu enunciado é geral e sucinto, Limita-se a repetir que a divisão do trabalho é um fato de ordem natural e tem as suas limitações, embora produza efeitos altamente desejáveis em têrmos de rendimento.

\section{O MELHOR MEIO DE UTILIZAR INDIVIDUUOS E GRUPOS}

"A divisão do trabalho é de ordem natural: no mundo animal, onde, quanto mais perfeito o ser, maior a variedade de órgãos encarregados de funções diferentes; e ocorre, igualmente, nas sociedades humanas, onde, quanto mais importante o corpo social, tanto maior e mais estreita a relação entre a função e o órgão. A medida que a sociedade cresce, novos órgãos surgem com a finalidade de substituir o órgão único primitivamente encarregado de tôdas as funções.

A divisão do trabalho tem por finalidade produzir mais e melhor com o mesmo esfôrço. O operário que faz diàriamente a mesma peça e o chefe que tem constantemente as mesmas ocupações adquirem habilidade, segurança e precisão que lhes aumentam o rendimento. Cada mudança de ocupação exige um esfôrço de adaptação que diminui a produção.

A divisão do trabalho permite reduzir o número de objetos sôbre os quais devem ser aplicados a atenção e o esfôrço. E' o melhor meio de utilizar os individuos e as coletividades.

Ela não se aplica sòmente às tarefas técnicas, mas a todos os trabalhos, sem exceção, que põem em jôgo um número mais ou menos grande de pessoas e que exigem muitos tipos de capacidade. E traz como conseqüência a especialização de funções e a separação de podêres.

Se bem que suas vantagens sejam universalmente reconhe cidas e que não se imagine a possibilidade de progresso sem o trabalho especializado dos sábios e artistas, a divisão do trabalho tem suas limitações, que a experiência, acompanhada do senso de medida, ensinam a respeitar". (3)

(3) Henri Fayol, Administration Industrielle et Gènèrale, Paris, 1950, p. 20-1. 
Os dois famosos primeiros capitulos de A Riqueza das Nações, dedica-os ADAM SMith à divisão do trabalho e suas fronteiras. Diferentemente de FAYOL, faz a apologia da divisão do trabalho e documenta com fatos por êle pessoalmente verificados no interior de fábricas os seus efeitos surpreendentes. O trecho produzido, parte inicial do primeiro capítulo, pode ser considerado amostra representativa da doutrina de AdAm SMITH sôbre a divisão do trabalho.

\section{A DIVISÃO DO TRABALHO NA INDÚSTRIA DE ALFINÊTES}

"O grande incremento das fôrças produtivas do trabalho e a maior parte do aumento de habilidade, destreza e discernimento dos trabalhadores parecem resultar da divisão do trabalho.

Os efeitos da divisão do trabalho nos negócios da sociedade em geral serão mais fàcilmente compreendidos se considerarmos a maneira pela qual ela funciona em certas manufaturas. Supõe-se, erradamente, que a divisão do trabalho seja mais avançada em emprêsas pequenas. E' que nas indústrias menos importantes, que se destinam a suprir a escassa procura de reduzido número de pessoas, o total de trabalhadores deve ser necessàriamente pequeno. Todos os que se encarregam de qualquer fase de seu trabalho são geralmente reunidos na mesma fábrica e podem ser vistos em conjunto pelo espectador. Já nas grandes indústrias, cujo fim é suprir as grandes necessidades de grande parte do povo, cada diferente fase do trabalho exige tão grande número de operários que é impossível reunir todos êles na mesma fábrica. Raramente podemos ver de uma só vez mais trabalhadores do que os que se ocupam de uma fase do trabalho. Ainda que em tais indústrias o trabalho possa estar dividido em um número muito maior de operações do que nas indústrias pequenas, a divisão aí não é tão clara. Por essa razão, torna-se menos patente.

Assim, vamos tomar o exemplo da manufatura de alfinêtes, em que a divisão do trabalho tem sido freqüentemente testemunkada. Um trabalhador não treinado para êste tipo de trabalho (que a divisão do trabalho tornou um ofício distinto), nem familiarizado com o uso da maquinaria nêle empregada (para a invenção da qual a mesma divisão do trabalho terá provàvelmente contribuído), esforçando-se ao máximo poderia fazer talvez um alfinête por dia, mas jamais conseguiria fazer vinte. No entanto, da maneira pela qual sua tarefa é atualmente realizada, não sòmente todo o trabalho é uma indústria peculiar, como também está dividido em numerosas operações, a maior parte das quais também constitui ofícios separados. Um operário puxa o arame, outro o endireita, um terceiro o corta, um quarto faz a ponta, 
um quinto lima o tôpo para receber a cabeça, cuja manufatura requer duas ou três operações diferentes; colocá-la é uma operação específica, dar-lhe brancura é outra; uma operação à parte é ainda colocar os alfinêtes no papel. A importante manufatura de alfinêtes é, desta maneira, dividida em dezoito operações diferentes. Vi uma pequena fábrica dêsse tipo onde havia sòmente dez operários. Alguns dêles, conseqüentemente, executavam duas ou três operações diferentes. Mas ainda que fôssem muito pobres, e, por isso, mediocremente adaptados às máquinas necessárias, podiam, quando se empenhavam, fazer cêrca de doze libras de alfinêtes por dia. Uma libra de alfinêtes de tamanho médio compreende mais de 4.000 . Fazendo cada operário, por êsse meio, a décima parte de 48.000 , podia ser considerado o manufaturador de 4.800 alfinêtes por dia. Mas se todos trabalhassem separado e independentemente, e não tivessem sido treinados para êsse trabalho específico, certamente nenhum poderia fazer vinte, talvez nem mesmo um alfinête por dia, isto é, nem a ducentésima quadragésima parte, provàvelmente nem mesma a quadrimilésima octingentésima parte do que eram capazes de fazer em conseqüência de uma divisão adequada de trabalho e combinação de suas diferentes operações". (4)

\section{IV}

Luther Gulick abre a teoria da organização com um capítulo sôbre a divisão do trabalho. Não há exagêro em afirmar-se que GuLIck conseguiu elaborar, ao mesmo tempo, uma teoria da divisão do trabalho, lastreando-a com exemplos imaginados, porém perfeitamente verossímeis e pragmáticos. Gulick raciocina que, como a divisão do trabalho é inevitável, mas supremamente benéfica ao homem quando feita de certa maneira, a coordenação se torna indispensável. "If subdivision of work is inescapable, co-ordination becomes mandatory", diz êle. E ensina que se coordena por duas vias: coordena-se pela predominância de uma idéia, como ocorre no caso de um grupo de fanáticos, e coordena-se por meio de organização. Daí a sua tese de que a divisão de trabalho é a razão de ser da organização.

\section{O FUNDAMENTO DA ORGANIZAÇÃO}

"O funcionamento de qualquer emprêsa complexa ou de vulto depende de numerosos homens. Onde quer que muitas pessoas estejam trabalhando juntas numa emprêsa, os melhores resultados são obtidos quando existe, entre elas, determinada divisão de trabalho. Conseqüentemente, a teoria de organização relaciona-se com a estrutura de coordenação imposta às unidades entre as

(4) Адам Sмiтh, The Wealth of Nations, vol. I. 
quais o trabalho de uma emprêsa esteja dividido. Dai não ser possivel determinar como deve ser organizada uma atividade, sem se considerar, simultâneamente, como o trabalho respectivo deve ser dividido.

A divisão do trabalho é o fundamento da organização; é em verdade a sua razão de ser.

\section{A DIVISÃO DO TRABALHO}

Cabe considerar aqui, no limiar da discussão, as razões e os efeitos da divisão do trabalho. Para o nosso propósito, é suficiente assinalar os fatôres abaixo indicados.

Por que dividir o trabalho?

Porque os homens diferem em natureza, capacidade, habilidade, e ganham grandemente em destreza pela especialização;

porque o mesmo homem não pode estar em dois lugares ao mesmo tempo;

porque um homem não é capaz de fazer duas coisas ao mesmo tempo;

porque a extensão dos conhecimentos e habilidades é tão grande que o homem não pode, no curso da vida, apreender mais do que uma pequena fração dos mesmos.

Em outras palavras, trata-se de uma questão de natureza humana, tempo e espaço.

Seria possível haver, por exemplo, mil operários em uma fábrica de calçados, cada um dos quais incumbido de fazer pares completos de sapatos. Assim, para um par de sapatos, cada operário cortaria o couro, colocaria os ilhoses, costuraria as diferentes peças, pregaria os saltos, enfiaria os atacadores, e, por fim, acondicionaria o produto acabado numa caixa. Talvez fôssem necessários dois dias para completar esta série de operações. Mil homens fabricariam, assim, 500 pares de calçados por dia.

Seria possível, igualmente, dividir-se o trabalho de modo inteiramente diverso entre êles, sem modificar os respectivos métodos manuais: um grupo ficaria incumbido de cortar o couro, outro de colocar os ilhoses, outro de chulear os rostos, outro de costurar as solas, outro de pregar os saltos e outro de enfiar os atacadores e acondicionar os pares de calçados. O senso comum ensina e a experiência confirma que o último processo oferece duas grandes vantagens: primeira torna possivel a melhor utilização das variadas habilidades e aptidões dos diferentes operários e estimula o desenvolvimento da especialização; segunda, elimina o tempo que o operário perde quando deixa a faca para usar o perfurador, pega a sovela, depois a agulha, passa desta ao burnidor, do burnidor ao martelo, e quando se move da mesa para o banco, do banco para a bigorna, desta para a banqueta. Sem nenhuma 
pressão sôbre os operários, êles provàvelmente poderiam produzir o dôbro, ou sejam mil pares de sapatos por dia. Haveria também economias adicionais, pois as operações de enfiar os atacadores e acondicionar os sapatos poderiam ser atribuidos a operários inqualificados e de salário menor. Além disso, no corte do couro haveria menos desperdício, porque os cortadores menos adestrados seriam naturalmente destacados para outro trabalho. Mediante o emprêgo de um pequeno esfôrço adicional, seria também possivel cortar uma dúzia de sapatos, ao mesmo tempo, pelo mesmo molde.

A introdução de máquinas, por sua vez, acentua a divisão do trabalho. Mesmo coisas simples como o serrote, a máquina de escrever ou o teodolito requerem maior especialização e servem para separar os trabalhadores em dois grupos: o dos que sabem e o dos que não sabem manejá-las efetivamente. Não resta dúvida de que a divisão do trabalho com base nas ferramentas e máquinas deriva em parte da aptidão, mas repousa, sobretudo, no desenvolvimento e manutenção da habilidade através de manipulação contínua.

Não é só o manejo de máquinas e ferramentas que desenvolve as habilidades especializadas. Estas emergem naturalmente dos materiais tratados, como a madeira, o gado, a pintura, o cimento; ocorrem, similarmente, em atividades que giram em tôrno de uma série complicada de técnicas, princípios e conceitos interrelacionados. Estas habilidades especializadas são mais claramente reconhecidas nas profissões, particularmente naquelas que, como a engenharia, a medicina e a química, se baseiam na aplicação do conhecimento científico; mas encontram-se não menos presentes no direito, na pedagogia, no sacerdócio, na contabilidade, navegação, aviação e outros campos.

A despeito de encerrarem uma parcela de lógica, essas subdivisões da atividade humana são essencialmente pragmáticas. Estão, pois, sujeitas a evoluir gradualmente com o avanço da ciência, com a invenção de novas máquinas, o progresso da tecnologia, a mudança do sistema social. Em última análise, entretanto, elas parecem basear-se nas diferenças individuais. Mas não se conclua dai que a estabilidade aparente da natureza humana - pouco importa o que isso venha a ser - limite o provável desenvolvimento da especialização. A situação é exatamente a oposta. A medida que cada ramo do saber e trabalho se amplia, constituindo um nexo continuamente maior e mais intrincado de princípios, práticas e habilidades, o ser humano será cada vez menos capaz de acompanhar êsse progresso, mantendo ainda conhecimento profundo sôbre a área inteira e agilidade de movimento em tôda ela. A especialização há de ser cada vez mais minudente, porque o conhecimento e a habilidade avançam, enquanto o homem permanece estacionário. 
A divisão do trabalho e a organização integrada constituem as alças com que a humanidade se eleva no processo da civilização.

\section{OS LIMITES DA DIVISÃO DO TRABALHO}

Há três limitações claras, além das quais a divisão do trabalho não pode ser levada, sob pena de se tornar desvantajosa. A primeira é prática e deriva do volume de trabalho relativo à jornada ou expediente de um trabalhador. Nada se ganha, evidentemente, como subdividir o trabalho se desta nova subdivisão resulta uma tarefa que requeira tempo menor que o tempo integral de uma pessoa. Isto é óbvio demais, não necessita de demonstração. A única exceção ocorre quando intervém o fator espaço. Nesse caso o empregado que trabalha apenas durante parte da jornada deve encher o tempo com outras tarefas de maneira que, na realidade, se opera uma nova combinação.

A segunda limitação surge da tecnologia e dos costumes vigentes em dado momento e lugar. Em certas regiões, por exemplo, nada se ganharia com tirar das igrejas o serviço funerário, visto que, pelo costume, o agente funerário acumula as funções de fabriqueiro; nas construções civis, também, em virtude dos conflitos de jurisdição das uniões trabalhistas, é extraordinàriamente dificil redividir certas fases do trabalho de eletricidade e encanamento e combiná-las de maneira mais efetiva; da mesma forma, implantar uma divisão de contabilidade de custo, em setor que ainda não haja desenvolvido a respectiva técnica, é nitidamente impraticável. Esta segunda limitação é patentemente elástica: tanto as invenções como a educação podem alterá-la. Se não fôsse assim, estariamos em face de uma divisão estática do trabalho. Deve-se notar, contudo, que uma grande mudança na divisão do trabalho envolve dois perigos, a saber: primeiro, restringe consideràvelmente 0 mercado de trabalho onde se possa recrutar os trabalhadores; segundo, diminui enormemente as oportunidades oferecidas àqueles que são treinados para a nova especialização.

A terceira limitação é, por assim dizer, a fronteira orgânica - em outras palavras, a subdivisão do trabalho deve ficar no plano físico, nunca entrar no plano orgânico. Com efeito, poderia parecer muito mais eficiente que a metade dianteira de uma vaca ficasse no campo pastando e a metade traseira no estábulo, em ordenha, tudo ao mesmo tempo - mas esta divisão orgânica produziria resultados negativos. Similarmente, não há vantagem $\mathrm{em}$ secionar um movimento ou gesto simples, como o de lamber um envelope, ou em picar uma série de atividades intima e intrincadamente relacionadas.

Pode-se alegar que há algo de vicioso neste raciocínio, pois que o teste aqui aplicado para saber se uma atividade é orgânica 
ou não consiste em verificar se a mesma é ou não divisivel e é isto o que estamos tentando definir. Convenhamos em que a objeção tem sua razão de ser. O teste deve ser essencialmente pragmático. Cumpre indagar: dá a divisão bons resultados? alguma coisa vital foi destruida ou perdida? há perda de substância?

\section{O TODO E AS PARTES}

E' axiomático que o todo é igual à soma de suas partes. Mas ao dividir qualquer "inteiro", deve o operador certificar-se de que tôdas as partes, inclusive os elementos e as relações invisiveis, são levadas em conta. A areia de mármore a que a estátua de Venus de Milo pode ser reduzida por um vândalo não seria igual à estátua, ainda que a última partícula fôsse preservada; tampouco um sabiá é simplesmente um tanto de penas, um tanto de ossos, um tanto de carne e um tanto de sangue; nem a máquina de escrever representa meramente tanto de aço, tanto de vidro, tanto de verniz e tanto de borracha. Pelo mesmo motivo, não se pode picar uma peça de trabalho em suas partes componentes obvias, sem correr o grande perigo de comprometer o designio central, a relação operante, a idéia prisioneira.

Uma simples ilustração tornará isto bem claro. Um homem sòzinho é capaz de construir uma casa, isto é: lançar os alicerces, cortar as vigas e espigões, lavrar e armar os portais, assentar o assoalho, levantar o teto, rebocar as paredes, colocar os canos d'água e aquecimento, fazer as instalações elétricas, colocar o papel e pintar tôda a casa. Mas se o fizer, a maior parte do trabalho será realizada por mãos inadestradas; haverá grande desperdício de material, além de que a obra lhe requererá muitos meses de esfôrço. Por outro lado, essa mesma tarefa de construir uma casa pode ser dividida entre vários homens. Um dêles poderá fazer os alicerces, erigir a chaminé e rebocar as paredes; outro poderá aşsentar o madeiramento, cortar as pranchas e tábuas, levantar o teto - numa palavra, fazer todo o serviço de carpintaria; outro se incumbirá do encanamento; outro, da pintura e colocação de papel nas paredes; outro das instalações elétricas. Entretanto, tudo isso junto não assumirá automàticamente a forma de casa, a menos que alguém - no caso um arquiteto - faça a necessária planta, de modo que cada oficial possa saber o que toca fazer e quando deve fazer a sua parte.

Quande um homem sòzinho constrói uma casa, êle planeja à medida que trabalha. Decide o que deve fazer primeiro e o que deixar para depois - isto é, "coordena o trabalho". Quando muitos indivíduos trabalham juntos na construção de uma casa, não se deve perder de vista esta parte da tarefa - a coordenação. 
$\mathrm{Na}$ "divisão do trabalho entre vários especialistas qualificados", é necessário, pois, incluir um especialista em planejamento e coordenação. Caso contrário, haverá grande desperdício de tempo, os trabalhadores interferirão nas tarefas uns dos outros, o material possivelmente não estará à mão quando necessário, as coisas poderão ser feitas em seqüência errada, assim como poderá mesmo haver diferenças de opinião sôbre o lugar, por exemplo, em que as várias portas e janelas devam ser assentadas.

Quanto mais o trabalho é subdividido, tanto maior é o perigo de confusão e, conseqüentemente, tanto mais imperiosa é a necessidade de fiscalização e coordenação de tôdas as suas partes. Essa afirmativa prescinde de demonstração. Agora, a coordenação não é algo que se desenvolva por acidente. Há que conquis. tá-la por meio de esfôrço inteligente, vigoroso, persistente e sistemático".

Falemos, agora, por conta própria:

\section{A DIVISÃo DO TRABALHO GOVERNAMENTAL}

Tôda e qualquer associação humana, da mais simples à mais transcendental, que se constitua para levar a efeito um propósito comum assume a forma de organização.

No momento em que dois trogloditas associaram, pela primeira vez, os seus esforços para realizar um fim comum a ambos - fôsse catar alimentos ou capturar animais perigosos - surgiu a primeira organização.

Dessa primeira fusão de esforços ao govêrno moderno, que é a mais complexa organização social até hoje conhecida, a distância percorrida pela capacidade dos homens para se "organizarem" em busca de objetivos comuns, pràticamente se confunde coni a medida do progresso humano. E é tão grande que atordoa: tão longa, tão extensa que quase chega a escapar ao alcance da própria imaginação. Contudo, a complexidade e o tamanho da organização governamental contemporânea nada mais representam do que uma expansão, em escala vertiginosa, daquela rudimentaríssima associação de esforços dos homens peludos das eras recuadas.

Efetivamente, o que hoje chamamos govêrno, exemplo eminente de associação humana, deliberadamente constituida e mantida para realizar propósitos coletivos, que se resumem, em última análise, na proteção e promoção do bem-estar geral, é uma organização como outra qualquer, distinguindo-se das demais apenas pelo seu caráter involuntário. De fato, ao passo que a participação de qualquer um em qualquer outra organização é voluntária

(5) LUTHER GuLick, op. cit., primeiro capitulo. 
ou espontânea, a participação de todos na organização pública é impositiva e inelutável.

A organização governamental pode assentar em estruturas diversas, assim como é suscetivel de vários graus de densidade, qualquer que seja a estrutura.

Os recentes progressos verificados no campo da Ciência Politica, confirmando, aliás, a observação leiga, vieram demonstrar que, quanto mais cresce a organização governamental em densidade, tanto mais evidente se torna a unidade imanente da instituição que denominamos govêrno. Daí o descrédito em que está caindo ràpidamente a clássica doutrina tripartida, que seciona o govêrno em três podêres distintos. Daí, igualmente, o advento da nova concepção, hoje aceita pela maioria dos cientistas políticos, de que o govêrno é, em essência, uma entidade orgânica e não um conjunto de elementos justapostos, um todo indivisível e não um grupo de podêres ou funções indepedentes - em suma, uma unidade e não uma trindade, ou pluralidade.

De acôrdo com os autores modernos, os órgãos e serviços que integram determinado govêrno, por numerosos e funcionalmente diferenciados que sejam, nada mais representam, pois, do que partes de uma só organização.

Apesar de tão luminosamente sistematizada a exposta por Montesquieu em seu famoso L'Esprit des Lois, e de tão entusiàsticamente decantada e difundida por quase todos os pensadores politicos que surgiram depois dêle, a doutrina da separação de podêres já não resiste à aferição da experiência, tendo consequüentemente deixado de ser válida. E se, embora bruxuleante, ainda circula em nossos dias, é porque se baseia numa tradição multissecular, tem a misteriosa respeitabilidade das coisas vetustas.

Segundo a concepção novíssima, cada govêrno nacional não se limita a ser uma unidade integrada, composta de órgãos que exercem ao mesmo tempo, em grau maior ou menor, funções politicas e funções administrativas. O govêrno moderno é mais do que isso: é uma emprêsa.

Com efeito, não é difícil de perceber - pois basta observar - que o govêrno nacional de nossos dias é uma vasta emprêsa politécnica, empenhada em planejar, organizar, dirigir, coordenar e controlar as mais diversas atividades, desde as essenciais, como a proteção à vida, até as opcionais, como o transporte de mercadorias e passageiros; desde as imemoriais, como a exação de impostos, até as moderníssimas, como o registro automático por meio da célula fotoelétrica dos veículos que passam em cada período de 24 horas ao longo de uma ponte ou através de um túnel; desde as rotineiras, como o pagamento de pessoal, até as eminentemente técnicas, como a aerofotogrametria; desde as mais simples, como a distribuição de correspondência, até as mais 
complexas, como o estudo dos ciclos econômicos; desde as inteiramente rudimentares, como a vigilância noturna, até as eminentemente científicas, como a pesquisa química, a previsão do tempo, o bombardeio dos eléctrons, o lançamento de satélites artificiais.

Em tôdas as épocas e em tôda a parte, onde e quando quer que um govêrno existiu, o seu trabalho houve de ser dividido para ser realizado, por isto que a divisão do trabalho é um fato natural, a que nenhuma emprêsa jamais poderá escapar.

No passado, antes do aparecimento da ciência da administração, o trabalho governamental era dividido exclusivamente por fôrça das circunstâncias. Tratava-se apenas das conseqüências perpétuas e imutáveis decorrentes das limitações naturais da capacidade humana. Desde que nenhum homem podia, como não pode, como nunca poderá, fazer duas ou mais coisas ao mesmo tempo, ou estar em dois ou mais lugares simultâneamente, ou saber fazer tôdas as coisas, sempre que havia trabalho idêntico em lugares diferentes, ou trabalho diferente no mesmo lugar, ou trabalho simultâneo no mesmo recinto, a sua divisão era inevitável, como há de ser eternamente.

Se era inevitável no govêrno antigo, que geralmente exercia poucas atividades, no govêrno moderno, tão sobrecarregado de funções novas e renovadas, a divisão do trabalho é inexorável.

Em verdade, o govêrno dos dias atuais teria impossibilidade física de desempenhar a miriade de funções que lhe congestionam o programa de ação se não dividisse, subdividisse e redividisse - seu trabalho. Mas ao passo que antigamente o trabalho era dividido, como já registramos, exclusivamente porque as circunstâncias assim o determinavam, depois que surgiu a administração cientifica, o trabalho deve ser dividido não apenas por fôrça daqueles fatôres, mas também, e sobretudo, de acôrdo com as indicações da experiência. Antes, o trabalho era simplesmente dividido porque tinha de ser. Hoje, graças aos conhecimentos acumulados, o trabalho deve ser dividido de certo modo, segundo certos princípios. Esses princípios, quando bem aplicados, possibilitam a melhor divisão de trabalho, conforme a prática tem demonstrado tão repetidas vêzes.

Sendo uma grande emprêsa, o govêrno moderno tende naturalmente a procurar aquela melhor divisão para o seu trabalho, no que é persuadido pela experiência.

Digamos, agora, entre parênteses, que a experiência que persuade o govêrno a dividir e subdividir o trabalho, não mais em obediência cega a circunstâncias incontornáveis, mas já agora à luz de determinados principios, é um dos elementos nucleares da nova ciência da administração.

Quando decorre ùnicamente das limitações com que certos fatôres rígidos e inapeláveis, notadamente o tempo e o espaço, 
cerceiam a capacidade humana, a divisão do trabalho é um fato natural, ou antes, uma fatalidade irredutivel, em face da qual não há alternativa.

Quando se cria, por exemplo, uma coletoria num municipio nôvo - com o que se introduz uma nova subdivisão geográfica no trabalho fiscal do govêrno - os fatôres determinantes da providência são, em primeiro lugar, o espaço, e em segundo, o tempo. Eis aqui um caso de divisão natural do trabalho, natural porque imposta pela fôrça de circunstâncias incontroláveis. Diante do fato irredutivel de que o coletor do municipio vizinho não pode estar em dois lugares ao mesmo tempo, se se quiser arrecadar impostos simultâneamente nos dois municipios, é imperioso que se incumbam indivíduos diferentes de fazê-lo.

Quando se cria uma segunda coletoria num dado município - subdividindo se, mais uma vez, o trabalho de arrecadar impostos - os fatôres determinantes, aqui também, são, em ordem decrescente, o tempo e o espaço. Pressupõe-se que a primeira coletoria já não seja suficiente para atender, dentro das horas regulamentares de trabalho, à massa de contribuintes. Além disso, para que a massa de contribuintes requeira uma segunda agência arrecadadora, é preciso que seja numerosa e, portanto, dispersa, embora no mesmo município ou no mesmo perímetro urhano. Logo, o fator espaço também influi, é verdade que muito menos do que o fator tempo, no desdobramento da primeira. Seria escusado dizer que aqui defrontamos outro exemplo de divisão natural do trabalho, igualmente tornada imperiosa pela influência combinada do tempo e do espaço. Diante da circunstância inexorável de que uma só coletoria já não pode vencer o volume de trabalho, se se quiser cobrar impostos de todos os contribuintes, a solução óbvia é criar outra.

Quando, já havendo coletorias suficientes, se cria, por exemplo, uma agência de correio na mesma área urbana - subdividindo-se, assim, novamente o trabalho governamental - , os fatôres determinantes são, ainda uma vez, as mesmas limitações de natureza humana. Diante da circunstância inalterável de que o homem não pode fazer duas coisas ao mesmo tempo - no caso, arrecadar impostos, receber e distribuir correspondência -, se se quiser que uma e outra sejam feitas, é imprescindivel que haja dois incumbentes diversos. Trata-se, idênticamente, de uma divisão natural do trabalho, imposta, como nos demais casos figurados, por fatôres inapeláveis.

Imaginemos, agora, que o coletor de um determinado municipio, embora sujeito ao regime de tempo integral, passe metade do dia de braços cruzados, por falta de trabalho bastante na sua repartição. Imaginemos ainda que, situado na vizinhança da coletoria, haja um hospital de caridade mantido pelo govêrno e cuja clientela não demaride mais do que metade do tempo de um profissional. 
Se os fatôres que limitam implacàvelmente as faculdades humanas fôssem apenas o tempo e o espaço, está bem visto que o coletor, empregado do mesmo govêrno, poderia desempenhar as duas funções - a de médico e a de coletor - dedicando a. cada uma delas metade do seu tempo. Seria mais econômico. para o govêrno e, conseqüientemente, para o público.

Todos sabemos, entretanto, que isso não se dá na sociedade. atual, porque, mesmo que disponha de tempo, o homem não pode. dominar bem senão uma parcela insignificante do conhecimento e da experiência, razão por que a necessidade da especialização também torna impositiva a divisão do trabalho. Assim, o fato de haver um individuo para arrecadar impostos e outro para tratar de enfermos, embora qualquer dos dois estivesse, relativamente ao tempo e ao espaço, em condições de exercer os dois encargos, é outro exemplo de divisão natural do trabalho. Em resumo, todos os casos que acabamos de supor, se se verificassem, seriam tipicas subdivisões naturais do trabalho.

Tôdas as vêzes que ocorrem as circunstâncias apontadas, o govêrno é forçado a subdividir o seu trabalho. Não é a ciência da administração que o aconselha, é o império das circunstâncias que o obriga a fazê-lo. Mas, ainda que assim obrigado, se o fizer deliberadamente de certo modo, segundo certos princípios, então é a conveniência, indicada pelo conhecimento, que o persuade a optar, dentre muitas, por uma forma de estruturar a divisão do trabalho.

O critério fundamental que rege tôda a ciência da administração é a eficiência. Na administração particular, a eficiência se transforma em lucro, que é a sua razão de ser. Na administração pública, a eficiência assume a forma de mais serviços, ou de menos tributação, ambas desejáveis. E' claro que a administração pública eficiente presta mais serviços com menos recursos, o que leva a dar mais aos contribuintes, ou então a exigir-lhes menos.

Em alguns casos, a divisão natural do trabalho permite a eficiência e, desta sorte, se conforma ao referido critério fundamental. As mais das vêzes, porém, a divisão natural do trabalho. só por si, não conduz à eficiência, caso em que pede corretivo.

O sistema conhecido por scientific management, com que. TAYLOR revolucionou a- arte de administrar, elevando-a à cate goria de ciência, tem por base o princípio de que, dentre os: mutitos possiveis, sempre há um melhor meio de realizar qualquer operação, inclusive de dividir o trabalho. Descobrir êsse meio é o ofício do organizador; pôrlo em prática, o do administrador.

Em contraposição à divisão natural, fato que, como já vimos, deriva de causas irremoviveis, algumas atuantes sôbre a natureza. humana, outras a ela inerentes, está emergindo lentamente, dos - limbos da incerteza, a teoria da organização científica do trabalho. 
A organização científica do trabalho não remove a divisão natural, até porque isso seria impossível, mas a afeiçoa ao principio da eficiência, mediante a aplicação de corretivos apropriados.

Quando dissemos, períodos atrás, que o govêrno moderno, ao dividir o seu trabalho, já não o faz apenas por imposição das circunstâncias, mas também por persuasão da experiência, tínhamos em mente o conjunto de regras da organização cientifica, que consiste em aplicar ao esfôrço associado, ou melhor, à emprêsa, uns tantos princípios hoje sazonados pela experiência.

O trabalho de tôda e qualquer emprêsa pode ser originàriamente dividido:

a) verticalmente;

b) horizontalmente;

c) vertical e horizontalmente.

O critério vertical, se levado às últimas conseqüências, conduz à divisão da massa total de trabalho por tantos órgãos autosuficientes quantas forem as funções principais que a emprêsa exercer. Isso quer dizer que cada um dêsses órgãos disporá de todos os recursos, em pessoal e material, necessários à realização dos propósitos que os animam.

As divisões ou departamentos verticais são homogêneos em propósitos, porque servem apenas a um, e heterogêneos em processos, porque utilizam muitos.

O critério horizontal, se rìgidamente adotado, conduz à divisão da massa total de trabalho por tantos órgãos mùtuamente dependentes quantos forem os processos principais que a emprêsa utilizar para atingir os seus fins. Isso significa que cada um dêsses órgãos conterá todos os recursos, em pessoal e material, tècnicamente ligados aos processos de que se utilizam.

As divisões ou departamentos horizontais são heterogêneos em propósitos, porque servem a todos, e homogêneos em processo, porque só se utilizam de um.

O critério misto, horizontal-vertical, amálgama dos anteriores, leva à divisão da massa total de trabalho por tantos órgãos interdependentes quantas forem as combinações de processos e propósitos que a experiência e o bom senso indicarem ao organizador. Isso significa que cada um dêsses órgãos conterá vários dos recursos, mas não todos, em pessoal e material, necessários à realização dos propósitos a que servem e à movimentação dos processos de que se servem.

As divisões ou departamentos mistos são heterogêneos por definição. 
Chama-se departamentalização a divisão primária do trabalho das grandes emprêsas. Trata-se de um dos capítulos importantes da teoria da organização.

\section{Post Scriptum}

\section{A DIVISÃO DO TRABALHO NO GOVÊRNO FEDERAL}

Tôda emprêsa de envergadura vê-se obrigada a dividir o trabalho. E' uma conseqüência das implacáveis limitações do homem: ou divide ou congestiona. E' uma exigência da lei do menor esfôrço: ou divide ou trabalha mais. E' um postulado do principio da coordenação: ou divide ou entra em caos. $E^{\prime}$ um. mandamento da administração cientifica: ou divide ou desperdiça. $\hat{\mathrm{E}}$, em suma, um imperativo categórico: ou divide ou perece.

Nas grandes emprêsas governamentais, o critério de divisão do trabalho afiançado pela experiência universal é o da especialização. Divide-se o trabalho verticalmente, de acôrdo com o principio da homogeneidade. No Govêrno Federal do Brasil, a divisão ideal do trabalho deveria obedecer a êsse critério. O Ministério das Minas e Energia cuidaria, especializadamente, dos negócios de minas e energia, jamais de questões de pessoal e outras da mesma família, comuns aos outros ministérios; o Ministério da Agricultura, dos negócios da produção vegetal e animal; o da Indústria e Comércio, dos assuntos pertinentes à expansão industrial e à normalidade comercial, e assim por diante. Esse critério oferece, entre outras, as vantagens seguintes:

Primo: permite que, em cada ministério, o ministro de Estado, seus assessôres e seu corpo de servidores concentrem as energias, a capacidade profissional, a experiência e os recursos materiais no estudo e solução dos problemas específicos, sem qualquer dispersão de esforços ou de atenção.

Secundo: atrai para cada ministério os profissionais correspondentes: os professôres e pedagogos para o Ministério da Educação; os médicos sanitaristas para o Ministério da Saúde; os engenheiros de minas e os geólogos para o Ministério das Minas; e assim por diante.

Tertio: enseja, em cada ministério, a acumulação de experiência e estimula o aprofundamento da especialização.

Nessa divisão, os fins do govêrno (justiça, educação, saúde, segurança, etc.) ficam a cargo dos diferentes ministérios. $E^{\prime}$ de bom aviso que isso aconteça: pela soma de interêsses sociais que envolvem, os fins do govêrno devem contar com órgãos especializados que a êles se dediquem de corpo e alma, com absoluta exclusividade. Os assuntos e negócios gerais, comuns a todos os ministérios, resvalam para a competência direta da Chefia Executiva. O Chefe Executivo, no caso do Brasil o Pre- 
sidente da República ou o Primeiro Ministro, fica assim responsável pelas atividades institucionais, também chamadas meios administrativos: pessoal, material, orçamento, planejamento geral, organização, métodos de trabalho, documentação etc. O Chefe Executivo passa a ser uma espécie de provedor-geral dos meios administrativos. Essa divisão do trabalho governamental fundamenta-se na lógica e no bom senso.

O pessoal, por exemplo, para ser bem administrado, requer normas gerais uniformes relativamente aos direitos e deveres. Antigamente, quando descentralizada a administração de pessoal, o Govêrno da União pagava um desenhista-chefe no ministério $A$ menos do que pagava a um desenhista de segunda classe no ministério $B$. Quanto ao material, basta lembrar que, só nos seis ministérios civis existentes em 1935, havia em uso 481 tipos diferentes de envelopes oficiais. O equipamento usado em cada ministério era escolhido de acôrdo com os gostos, os caprichos e até as esciuisitices das autoridades compradoras, jamais de acôrdo com determinadas especificações tecnológicas, tendentes a trazer economia e assegurar confôrto. Era, em suma, o reinado do caos na odministração dos meios.

O remédio especifico contra a administração anárquica é a centralização dos meios de ação na Chefia Executiva. Na administração de pessoal, a centralização oferece muitas vantagens:

a) uniformiza as relações de emprêgo entre o Estado e os servidores públicos, assegurando igualdade de direitos, deveres e oportunidades;

b) permite o tratamento profissional dos problemas envolvidos, porque os técnicos de pessoal têm volume de trabalho especializado suficiente para os manter ocupados todo o tempo;

c) reduz o custo unitário das operações de recrutamento, scleção, treinamento e aperfeiçoamento;

d) atrai maior número de candidatos para o serviço público, aumentando assim a probabilidade de eficiência da seleção;

e) evita ou minimiza as nomeações interinas, ou seja o ingresso, no serviço público, de pessoas impreparadas ou de simples cavadores.

$\mathrm{Na}$ administração de material, a centralização traz as seguintes vantagens:

a) reduz os atos administrativos, os contatos com os fornecedores, o número de concorrências públicas e o volume de papéis;

b) estimula a padronização dos materiais de consumo, móveis e equipamento de escritório;

c) cria condições para a existência de compradores especializados, progressivamente mais familiarizados com os artigos, os fornecedores, os avanços industriais; 
d) em suma, produz uma economia de 10 até $25 \%$ na aquisição de material, o que, no caso do Govêrno Federal do Brasil, representa bilhões de cruzeiros por ano. $\mathrm{Na}$ administraçăo dos demais meios administrativos, a centralização gera condições para a obtenção de vantagens semelhantes, ora econômicas, ora funcionais, ora de cooperação.

Ocorre que o Chefe Executivo também está sujeito às limitações humanas - físicas, intelectuais, profissionais e outras. Não the sendo possivel desempenhar pessoalmente tôdas as funções pertinentes à administração de pessoal, financeira, de material, de orçamento, de documentação e outras da mesma familia, é forçado a recorrer à divisão horizontal do trabalho e fazer aquilo a que GuLIck chama "institucionalização da Chefia Executiva".

A institucionalização da Chefia Executiva pressupõe a existência de departamentos de administração geral, de que o D.A.S.P. é um dos espécimes mais representativos, segundo tem sido proclamado por tantas autoridades em matéria de administração. 